\title{
Multi-criteria thermal evaluation of wall enclosures of high-rise buildings insulated products based on modified fibers
}

\author{
Alexey Pavlov ${ }^{*}$, Larisa Pavlova ${ }^{1}$, and Lyudmila Pavlova ${ }^{1}$ \\ ${ }^{1}$ Samara Architectural and Civil Engineering University, 443001, Molodogvardeyskaya str., 194, \\ Samara, Russia
}

\begin{abstract}
In article results of research of versions of offered types of heaters on the basis of products from the modified fibers for designing energy efficient building enclosures residential high-rise buildings are presented. Traditional building materials (reinforced concrete, brick, wood) are not able to provide the required value of thermal resistance in areas with a temperate and harsh Russia climate in a single-layered enclosing structure. It can be achieved in a multi-layered enclosing structure, where the decisive role is played by new insulating materials with high thermal properties. In general, modern design solutions for external walls are based on the use of new effective thermal insulation materials with the use of the latest technology. The relevance of the proposed topic is to research thermoinsulation properties of new mineral heaters. Theoretical researches of offered heaters from mineral wool on slime-colloidal binder, bentocolloid and microdispersed binders are carried out. In addition, theoretical studies were carried out with several types of facade systems. Comprehensive studies were conducted on the resistance to heat transfer, resistance to vapor permeation and air permeability. According to the received data, recommendations on the use of insulation types depending on the number of storeys of buildings are proposed.
\end{abstract}

\section{Introduction}

External walls for energy-efficient buildings are designed by multilayer in accordance with [1] with the use of effective thermal insulation materials. With the advent of new materials and systems of enclosing structures, great attention should be paid to understanding the physical processes occurring in the external walls, for their competent design and construction [2-4].

In addition to calculating the resistance to heat transfer, it is necessary to calculate the moisture state. Resistance to heat transfer, determined at the surface of the wall, is significantly different from the reduced resistance to heat transfer of the outer wall due to the presence and influence of window slopes, exterior corners of walls, partitions, ceilings, heat-conducting inclusions [5-7].

\footnotetext{
${ }^{*}$ Corresponding author: adisk63@yandex.ru
} 
The loss of condensate in multilayered enclosing structures leads to an increase in the humidity of building and thermal insulation materials and to a deterioration in their heatshielding properties. There is a need for calculating the moisture regime of building structures $[8,9]$, since for an annual period of building operation there is accumulation of moisture inside the enclosing structure.

For a long time, the authors carried out theoretical studies of facade systems of multilayered wall fences [10-13], experimental studies [14-16] with various types of known insulants. The proposed work is devoted to the study of facade systems with insulation on new types of binders [17-19].

\section{Materials and Methods}

Theoretical studies were carried out with three options for the proposed insulation:

a) mineral wool on slime-colloidal binder;

b) mineral wool on bentocolloid binder;

c) mineral wool on microdispersed binder.

Depending on the location of the heater in the enclosure used two options for insulation:

- insulation - inside the enclosing structure;

- insulation - outside the enclosing structure.

In outside thermoinsulation two systems were used:

1 - plastering;

2 - front facing.

Advantages of the building technology of facade systems with air gap over singlewalled walls have been known for a long time: air circulation and thermal radiation in the air gap provides a rapid removal of moisture from the interior of the building, supporting walls, insulation.

The multi-storey residential building in Samara has been calculate. The exterior wall constructions for theoretical substantiation have been checked in three versions, with an experimental insulation in three variants. Schemes of wall constructions and options for insulation are presented in Table 1.

Table 1. Constructions of the investigated walls and the options for insulation

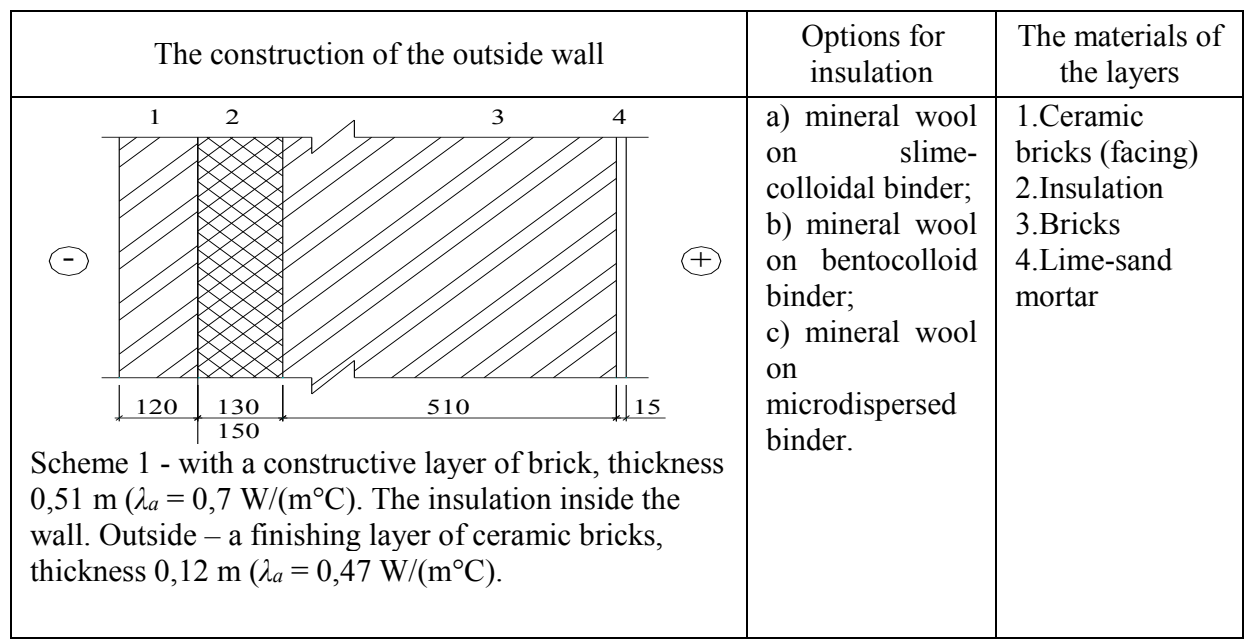




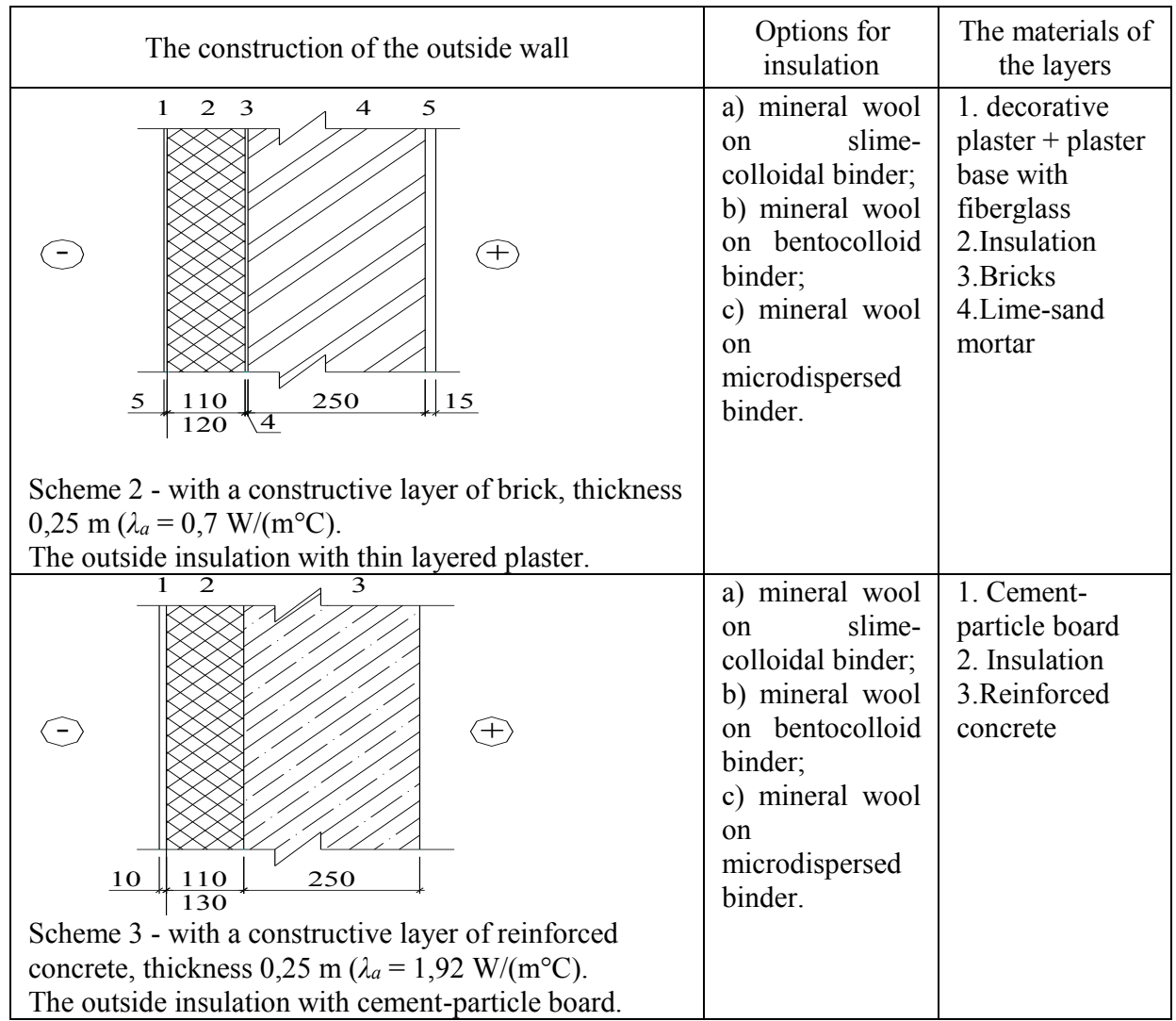

The technique of thermal calculation was based on the requirements [1] using the graphical method and the method of dimensionless characteristics for humidity areas. The method of calculation humidity conditions of external walls according to the method of dimensionless characteristics includes the determination of vapour pressure in the typical design cross sections for the annual cycle. If the vapor pressure exceeds the maximum elasticity of steam, in this section, the formation of condensate.

The basis of the constructive solutions of the exterior walls in determining the given resistance to heat transfer of the main fragments of the railings take the thickness of the insulation calculated in accordance with [1]. In case of insufficiency of insulation, thickness of insulation layer increases, or considering or considering the possibility of inclusion in the project energy saving measures (insulation of nodes).

The results of calculation of constructive schemes of walls 1-3 with options of insulation for residential buildings in Samara are presented in table 2.

Table 2. Results of structural analysis of the wall heat transfer resistance and water vapor

\begin{tabular}{|c|c|c|c|c|c|}
\hline $\begin{array}{c}\text { Construction } \\
\text { scheme }\end{array}$ & $\begin{array}{c}\text { Options } \\
\text { for insulation }\end{array}$ & $\begin{array}{c}\text { Insulation } \\
\text { thickness, } m\end{array}$ & $\begin{array}{c}\text { Thermal } \\
\text { resistance } R o, \\
m^{2 \cdot}{ }^{\circ} C / W\end{array}$ & $\begin{array}{c}\text { Resistance } \\
\text { vapor } \\
\text { permeation } R_{n}, \\
m^{2} \cdot h \cdot P a / m g\end{array}$ & $\begin{array}{c}\text { Required } \\
\text { resistance } \\
\text { vapor } \\
\text { permeation } \\
R_{n}{ }^{m p}, \\
M^{2} \cdot y \Pi a / m 2\end{array}$ \\
\hline \multirow{3}{*}{1} & a) & 0,15 & 4,914 & 5,125 & 5 \\
\hline & b) & 0,15 & 4,787 & 5,08 & 4,95 \\
\hline & c) & 0,13 & 4,374 & 5,363 & 5,345 \\
\hline 2 & a) & 0,11 & 3,3 & 2,764 & 0,065 \\
\hline
\end{tabular}




\begin{tabular}{|c|c|c|c|c|c|}
\hline \multirow{3}{*}{3} & b) & 0,12 & 3,448 & 2,752 & 0,066 \\
\cline { 2 - 6 } 3 & c) & 0,11 & 3,265 & 3,01 & 0,067 \\
\hline & a) & 0,11 & 3,08 & 8,6 & 0,046 \\
\cline { 2 - 6 } & b) & 0,13 & 3,467 & 8,61 & 0,047 \\
\hline & c) & 0,12 & 3,29 & 8,89 & 0,045 \\
\hline
\end{tabular}

Calculations of temperature fields were carried out according to the design schemes 1-3 in the thickness of the external walls using the specialized program THERM 5.2. The results are shown in Figures 1, 2 and Table 3.

The necessity of calculation for the accumulation and condensation of moisture in building enclosures were improved.

The outer joints of the walls to the three options of heaters 1c), 2a), 3a) was chosen for thermal estimates of temperature change over the cross section of the walls.

The junction of walls with insulation inside the structure (layered masonry - see Figure 1a, 1b) does not pass heat transfer resistance $\left(R_{0}=2,35\left(\mathrm{~m}^{2.0} \mathrm{C}\right) / \mathrm{W}<R^{\text {req }}\right)$, but passes sanitary and hygienic conditions $\left(\Delta t=3,8{ }^{0} \mathrm{C} \leq \Delta t^{n}=4{ }^{0} \mathrm{C}\right.$, as $t_{\text {int }}=16,9{ }^{\circ} \mathrm{C}>t_{d}=16,2{ }^{\circ} \mathrm{C}$ dew point).

Table 3. Results of calculation of temperature fields on the THERM 5.2

\begin{tabular}{|c|c|c|c|c|c|c|c|c|}
\hline \multicolumn{2}{|c|}{$\begin{array}{c}\text { Construction } \\
\text { scheme }\end{array}$} & $\begin{array}{l}\text { No. of } \\
\text { point } \\
\text { starting } \\
\text { from the } \\
\text { outside } \\
\text { surface } \\
\end{array}$ & $T,{ }^{0} \mathrm{C}$ & $E, \mathrm{~Pa}$ & $e, \mathrm{~Pa}$ & $\begin{array}{c}\text { Conditio } \\
\mathrm{n} \\
e \leq E\end{array}$ & $\begin{array}{c}R_{0,} \\
m^{2.0} \mathrm{C} / W\end{array}$ & $\begin{array}{l}\text { Recommendation } \\
\mathrm{s}\end{array}$ \\
\hline \multirow{3}{*}{1} & $\mathrm{a}$ & $\begin{array}{l}1 \\
2 \\
3 \\
4 \\
5\end{array}$ & $\begin{array}{c}-27,6 \\
-25,1 \\
11,9 \\
19,1 \\
19,3\end{array}$ & $\begin{array}{c}48 \\
62 \\
1323 \\
2210 \\
2238\end{array}$ & $\begin{array}{c}720 \\
788,53 \\
823,77 \\
1273,87 \\
1286\end{array}$ & $\begin{array}{l}- \\
- \\
+ \\
+ \\
+\end{array}$ & 4,914 & \multirow{3}{*}{$\begin{array}{l}\text { Increased thickness } \\
\text { insulation from } 0.11 \\
\mathrm{~m} \text { to } 0.15 \mathrm{~m} \text {, based o } \\
\text { the calculation of } \\
\text { resistance to vapor } \\
\text { permeation }\end{array}$} \\
\hline & $\mathrm{b}$ & $\begin{array}{l}1 \\
2 \\
3 \\
4 \\
5 \\
\end{array}$ & $\begin{array}{c}-27,6 \\
-25 \\
11,7 \\
19 \\
19,3\end{array}$ & $\begin{array}{c}48 \\
63 \\
1375 \\
2197 \\
2238 \\
\end{array}$ & $\begin{array}{c}720 \\
789,07 \\
820,19 \\
1273,77 \\
1286\end{array}$ & $\begin{array}{l}- \\
- \\
+ \\
+ \\
+\end{array}$ & 4,787 & \\
\hline & $\mathrm{c}$ & $\begin{array}{l}1 \\
2 \\
3 \\
4 \\
5\end{array}$ & $\begin{array}{c}-27,6 \\
-24,7 \\
10,9 \\
19 \\
19,2\end{array}$ & $\begin{array}{c}48 \\
64 \\
1304 \\
2197 \\
2225\end{array}$ & $\begin{array}{c}720 \\
785,84 \\
841,99 \\
1274,34 \\
1286\end{array}$ & $\begin{array}{l}- \\
- \\
+ \\
+ \\
+\end{array}$ & 4,374 & \\
\hline \multirow{3}{*}{2} & $\mathrm{a}$ & $\begin{array}{l}1 \\
2 \\
3 \\
4 \\
5 \\
6\end{array}$ & $\begin{array}{l}-27,4 \\
-27 \\
12,9 \\
13,3 \\
18,6 \\
18,9\end{array}$ & \begin{tabular}{|c|}
48 \\
51 \\
1488 \\
1527 \\
2142 \\
2182
\end{tabular} & $\begin{array}{c}720 \\
742,04 \\
794,39 \\
814,07 \\
1261,40 \\
1286\end{array}$ & $\begin{array}{l}- \\
- \\
+ \\
+ \\
+ \\
+ \\
+\end{array}$ & 3,3 & \multirow{3}{*}{$\begin{array}{l}\text { The wall constructio } \\
\text { meets all } \\
\text { requirements of hea } \\
\text { engineering with the } \\
\text { least thickness of } \\
\text { insulation. } \\
\text { The barrier structure } \\
\text { has low vapor } \\
\text { permeability }\end{array}$} \\
\hline & b & $\begin{array}{l}1 \\
2 \\
3 \\
4 \\
5 \\
6 \\
\end{array}$ & $\begin{array}{c}-27,6 \\
-27,4 \\
13 \\
13,6 \\
18,7 \\
19\end{array}$ & \begin{tabular}{c|}
48 \\
48 \\
1497 \\
1557 \\
2156 \\
2197 \\
\end{tabular} & $\begin{array}{c}720 \\
742,13 \\
792,33 \\
812,09 \\
1261,30 \\
1286\end{array}$ & $\begin{array}{l}- \\
- \\
+ \\
+ \\
+ \\
+\end{array}$ & 3,448 & \\
\hline & $\mathrm{c}$ & $\begin{array}{l}1 \\
2 \\
3 \\
4 \\
5 \\
6\end{array}$ & $\begin{array}{c}-27,4 \\
-27,3 \\
13,1 \\
13,3 \\
18,6 \\
18,9\end{array}$ & $\begin{array}{c}48 \\
49 \\
1508 \\
1527 \\
2142 \\
2182 \\
\end{array}$ & $\begin{array}{c}720 \\
740,32 \\
832,69 \\
850,84 \\
1263,32 \\
1286\end{array}$ & $\begin{array}{l}- \\
- \\
+ \\
+ \\
+ \\
+\end{array}$ & 3,265 & \\
\hline 3 & $\mathrm{a}$ & 1 & $-27,5$ & 48 & 720 & - & & The wall is \\
\hline
\end{tabular}




\begin{tabular}{|c|c|c|c|c|c|c|c|}
\hline $\begin{array}{c}\text { Construction } \\
\text { scheme }\end{array}$ & $\begin{array}{c}\text { No. of } \\
\text { point } \\
\text { starting } \\
\text { from the } \\
\text { outside } \\
\text { surface }\end{array}$ & $T,{ }^{0} \mathrm{C}$ & $E, \mathrm{~Pa}$ & $e, \mathrm{~Pa}$ & $\begin{array}{c}\text { Conditio } \\
\mathrm{n} \\
e \leq E\end{array}$ & $\begin{array}{c}R_{0}, \\
m^{2.0} \mathrm{C} / W\end{array}$ & $\begin{array}{l}\text { Recommendation } \\
\mathrm{s}\end{array}$ \\
\hline & $\begin{array}{l}2 \\
3 \\
4\end{array}$ & $\begin{array}{c}-27,2 \\
16,8 \\
18,8\end{array}$ & $\begin{array}{l}49,3 \\
1913 \\
2169\end{array}$ & $\begin{array}{c}736,80 \\
753,78 \\
1286\end{array}$ & $\begin{array}{l}- \\
+ \\
+\end{array}$ & 3,08 & \multirow{3}{*}{$\begin{array}{l}\text { designed to meet } \\
\text { all the requirements } \\
\text { of heat engineering. } \\
\text { Non-optimal values } \\
\text { of resistance to heat } \\
\text { transfer }\end{array}$} \\
\hline b & $\begin{array}{l}1 \\
2 \\
3 \\
4\end{array}$ & $\begin{array}{c}-27,5 \\
-27,3 \\
17,1 \\
19\end{array}$ & $\begin{array}{c}48 \\
49 \\
1949 \\
2197\end{array}$ & $\begin{array}{c}720 \\
725,34 \\
743,25 \\
1286\end{array}$ & $\begin{array}{l}- \\
- \\
+ \\
+\end{array}$ & 3,467 & \\
\hline $\mathrm{c}$ & $\begin{array}{l}1 \\
2 \\
3 \\
4\end{array}$ & $\begin{array}{c}-27,4 \\
-27,2 \\
17 \\
18,9\end{array}$ & $\begin{array}{c}48 \\
49,3 \\
1937 \\
2182\end{array}$ & $\begin{array}{c}720 \\
725,24 \\
760,25 \\
1286\end{array}$ & $\begin{array}{l}- \\
- \\
+ \\
+\end{array}$ & 3,29 & \\
\hline
\end{tabular}

a
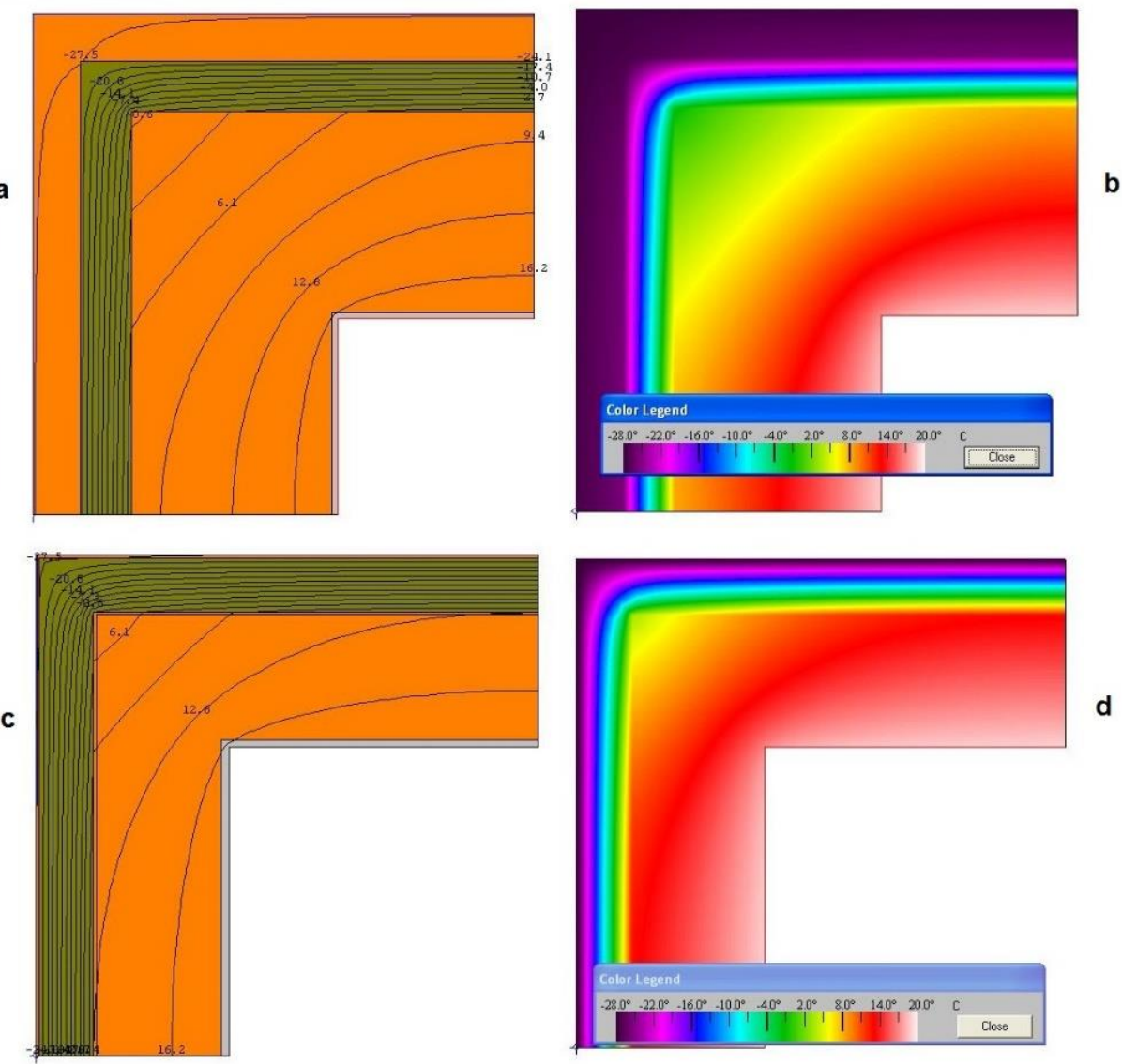

Fig. 1. Temperature fields along the cross-section of the outer joint of the walls:

a - temperature isotherms according to scheme 1c);

$\mathrm{b}$ - temperature distribution according to scheme 1c);

c - temperature isotherms according to scheme $2 \mathrm{a}$ );

$\mathrm{d}$ - temperature distribution according to scheme $2 \mathrm{a}$ ) 
The junction of walls, insulated on the outside (Fig. 1c, 1d) with fine plaster without the vapor barrier, the most effective $\left(R_{0}=2,366\left(\mathrm{~m}^{2.0} \mathrm{C}\right) / \mathrm{W}\right.$, more than 2,35) and passes the sanitary and hygienic conditions $\left(\Delta t^{f}=3,8{ }^{\circ} \mathrm{C} \leq \Delta t^{n}=4{ }^{\circ} \mathrm{C}\right.$, as $\left.t_{\text {int }}=16,6{ }^{\circ} \mathrm{C}>t_{d}=16,2{ }^{\circ} \mathrm{C}\right)$.

The junction of walls, insulated on the outside (Fig.2 1a, 1b) with facing of the CPB does not pass on the resistance to heat transfer $\left(R_{0}=2,333\left(\mathrm{~m}^{2.0} \mathrm{C}\right) / \mathrm{W}\right.$ which is $\left.\leq R^{\text {req }}\right)$, but passes the sanitary and hygienic conditions $\left(\Delta t=3,8{ }^{\circ} \mathrm{C} \leq \Delta t^{n}=4{ }^{0} \mathrm{C}\right.$, as $t_{\text {int }}=17,2{ }^{\circ} \mathrm{C}>t_{d}=$ $\left.16,2{ }^{\circ} \mathrm{C}\right)$. The insulation of the joint is required.
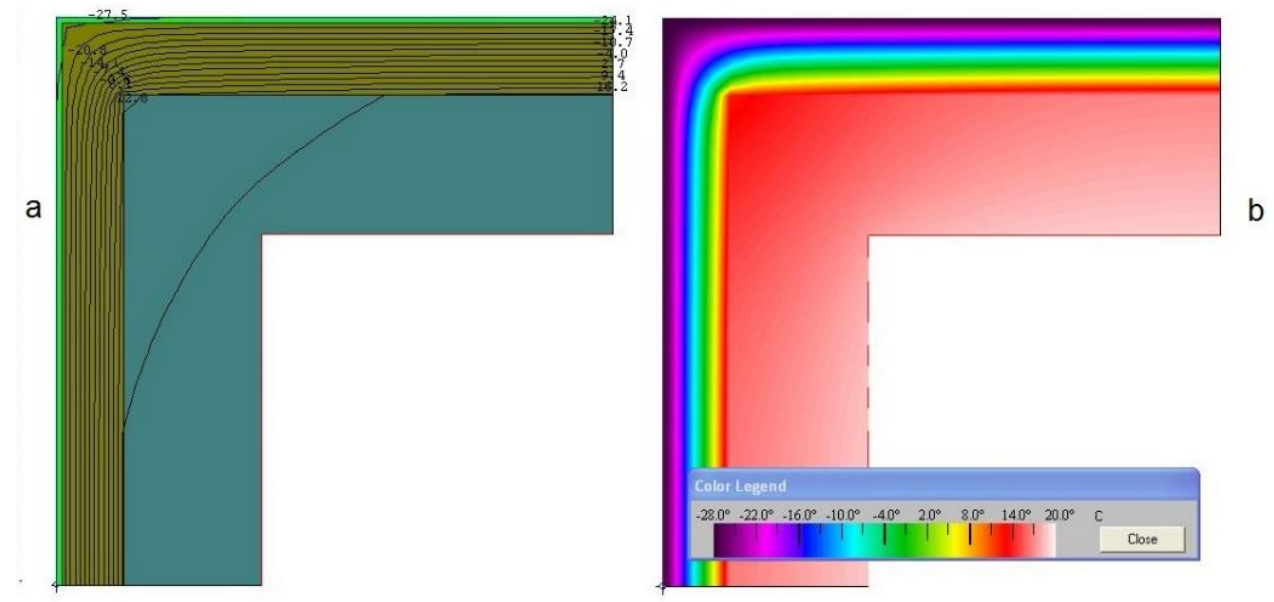

Fig. 2. Temperature fields along the cross-section of the outer joint of the walls:

a - temperature isotherms according to scheme $3 a$ );

$\mathrm{b}$ - temperature distribution according to scheme $3 \mathrm{a}$ );

Resistance to air permeability of building envelopes and structures $R_{\text {inf }}$ des $_{\text {should not be }}$ less than specified resistance to air permeability $R_{\text {inf }}^{\text {req }}, \mathrm{m}^{2} \cdot \mathrm{h} \cdot \mathrm{Pa} / \mathrm{kg}$, determined by the formula (1):

$$
R_{\mathrm{inf}}^{r e q}=\frac{\Delta p}{G_{n}},
$$

where $\Delta P$ - pressure difference of the air at the exterior and interior surfaces of building envelopes, $\mathrm{Pa}$;

$G_{n}$ - normalized air permeability of building envelopes, $\mathrm{kg} /\left(\mathrm{m}^{2} \cdot \mathrm{h}\right)$.

The pressure difference of the air on the outer and inner surfaces of enclosing structures, the $\mathrm{Pa}$, to the windward side were determined according to [1], $G_{n}$ the normalized air permeability, $\mathrm{kg} /\left(\mathrm{m}^{2} \cdot \mathrm{h}\right)$, at the table 9 [20]. Breathability $G_{n}, \mathrm{~kg} /(\mathrm{m} 2 \cdot \mathrm{h})$, the exterior walls must be not more than 0,5 .

Was determined pressure difference of the air on the outer and inner surfaces of walling on the ground floor of the building with the height of buildings $20,40,60,100 \mathrm{~m}$, and the normalized resistance to air permeability $R_{\text {inf }}^{\text {req }}$. According to the calculations on the water vapor permeability of scheme 3 based on resistance to air permeability of structures is not necessary. In the walls according to schemes 1 and 2, there are layers of plaster, which have a sufficiently high value of the resistance to air permeability.

The results of the structural analysis of walls with an experimental insulation on air permeability is presented in table 4 . 
Table 4. Results of the design of walls with experimental insulation for air permeability (scheme 1)

\begin{tabular}{|c|c|c|c|c|c|c|c|c|}
\hline Scheme 1 & $H, \mathrm{~m}$ & $\begin{array}{c}R_{\text {inf furb }} \text { ins } \\
\mathrm{m}^{2} \cdot \mathrm{h} \cdot \mathrm{Pa} / \mathrm{kg}\end{array}$ & $\begin{array}{c}R_{i n f}^{\text {des }} \\
\mathrm{m}^{2} \cdot \mathrm{h} \cdot \mathrm{Pa} / \mathrm{kg}\end{array}$ & $\begin{array}{c}R_{\text {inf }}^{\text {des }}, \\
\mathrm{m}^{2} \cdot \mathrm{h} \cdot \mathrm{Pa} / \mathrm{kg}\end{array}$ & $\Delta p_{i}$, Па & $\begin{array}{l}\text { Condition } \\
R_{\text {inf }}^{\text {des }} \geq \\
R_{\text {inf }} \geq\end{array}$ & $\begin{array}{l}\text { Height, } \\
H_{\text {onm }}, \mathrm{m}\end{array}$ & $\begin{array}{l}\text { No. of } \\
\text { storeys }\end{array}$ \\
\hline $\begin{array}{l}\text { a) mineral } \\
\text { wool on } \\
\text { slime- } \\
\text { colloidal } \\
\text { binder }\end{array}$ & $\begin{array}{c}20 \\
40 \\
60 \\
100\end{array}$ & $\begin{array}{l}38,21 \\
49,42 \\
58,51 \\
73,40\end{array}$ & $\begin{array}{c}75,54 \\
126,36 \\
177,18 \\
278,82\end{array}$ & $\begin{array}{l}218,41 \\
229,62 \\
238,71 \\
253,60\end{array}$ & $\begin{array}{c}37,77 \\
63,18 \\
88,59 \\
139,41\end{array}$ & $\begin{array}{l}+ \\
+ \\
+ \\
-\end{array}$ & 88,5 & 30 \\
\hline $\begin{array}{l}\text { b) mineral } \\
\text { wool on } \\
\text { bentocolloid } \\
\text { binder }\end{array}$ & $\begin{array}{c}20 \\
40 \\
60 \\
100\end{array}$ & $\begin{array}{l}22,82 \\
29,51 \\
34,95 \\
43,84\end{array}$ & $\begin{array}{c}75,54 \\
126,36 \\
177,18 \\
278,82\end{array}$ & $\begin{array}{l}203,02 \\
209,71 \\
215,15 \\
224,04\end{array}$ & $\begin{array}{c}37,77 \\
63,18 \\
88,59 \\
139,41\end{array}$ & $\begin{array}{l}+ \\
+ \\
+ \\
-\end{array}$ & 76 & 25 \\
\hline $\begin{array}{l}\text { c) mineral } \\
\text { wool on } \\
\text { microdispers } \\
\text { ed binder. }\end{array}$ & $\begin{array}{c}20 \\
40 \\
60 \\
100\end{array}$ & $\begin{array}{c}69,41 \\
89,77 \\
106,30 \\
133,35\end{array}$ & $\begin{array}{c}75,54 \\
126,36 \\
177,18 \\
278,82\end{array}$ & $\begin{array}{l}249,61 \\
269,97 \\
286,50 \\
313,55\end{array}$ & $\begin{array}{c}37,77 \\
63,18 \\
88,59 \\
139,41\end{array}$ & $\begin{array}{l}+ \\
+ \\
+ \\
+\end{array}$ & 117 & 40 \\
\hline
\end{tabular}

\section{Discussion}

1. Heat and humidity calculations showed that the investigated insulation can be applied in the system with an outer insulated layer and using them in construction with brick facing, along with basalt wool ROCKWOOL or polyester staple fiber URSA. All of the investigated insulation are non - combustible and environmentally friendly, which is one of the important factors in the structural design of the wall.

2. The design of the system with external insulation and thin plaster layer is achieved by the high thermal uniformity of the insulated exterior walls. The durability of the facade before the first overhaul is about 25 years. The comparison of the three schemes of wall constructions the wall construction with external insulation has more advantages for all types of characteristics. Dew point is shifted to the outer wall surface that prevents the accumulation of moisture in the thickness of the structure. Other advantages of this system is the lack of a vapor barrier, the possibility of realization of various architectural solutions, high maintainability.

3. Calculations on the resistance to vapor deposition and air permeability of the enclosing structures of residential buildings with insulation based on modified fibers (three schemes of wall constructions) have been shown:

- experimental insulation can be used in walls of residential buildings frameless construction system with insulation on the outside and frame system with brick facing, as they satisfy all heating requirements: resistance to heat, water vapor and lack of moisture in the enclosing structures of buildings;

- according to the resistance to air permeability, the proposed heaters are recommended for high-rise buildings. More effective from experimental insulants based on mineral fibers - using a microdispersed modifier, which can be used in buildings up to 40 storeys;

- in the construction of walls with facing brick and a thickness of the structural layer of $51 \mathrm{~cm}$ there is an increase of $1 \mathrm{~cm}$ in thickness of the proposed insulation - mineral wool 
slabs with a microdispersed modifier does not require a vapor barrier layer and allows to meet the requirements of heat engineering in all respects. Other experimental heaters ensure the requirements of standards with an increase in thickness by $3 \mathrm{~cm}$.

4. Studies and analysis of the results on air permeability showed that the proposed TIM on the basis of technogenic raw materials can be used in buildings up to 26 floors, and in some cases up to 40 , whereas with a mineral wool insulation on a bentocolloid binder does not exceed 24 floors. The use of man-made waste as modifiers of polyfunctional action of heat-insulating materials allows to reduce the thickness of the insulation in comparison with the TIM on the bentocolloid binder.

\section{References}

1. Russian State Standard SP 50.13330.2012. Thermal performance of the buildings.

2. L. V. Pavlova, Insulation of walls and their interfaces. Abstracts/Tradition and innovation in construction and architecture: materials of the 67th scientific and technical conference on the results of the research in 2009. H.9/SGASU, 705-706 (Samara, 2010).

3. L. V. Pavlova, The Reliability and quality of thermal insulation of buildings, Vestnik SGASU. Urban planning and architecture scientific-technical journal, 4(12), 99-105 (Samara, 2013)

4. L. V. Pavlova, the Thermal protection of buildings, 40 (Samara, SGASU, 2011)

5. L. V. Pavlova, the Modern energy saving of the building envelope, Wall: textbook, 72 (Samara: SGASU, 2012) ISBN 978-5-9585-0461-9

6. L. V. Pavlova, A. A. Pavlov, Study of moisture in exterior walls//Actual problems in construction and architecture, Education. Science. Practice/regional Materials 59 technical conference, 407-408 (Samara, SamGASA 2002)

7. L. V. Pavlova, A. A. Pavlov, Study of moisture in the material of the exterior walls, Modern investment processes and construction technologies/proceedings of the section "Construction" of the Russian Academy of engineering, 2, 211-217 (Moscow, 2002)

8. L. V. Pavlova, the Reliability and quality of thermal insulation of buildings. Abstracts, Tradition and innovation in construction and architecture: materials of the 68th scientific and technical conference on the results of research for 2010, 11, 868-869 (Samara, 2011)

9. L. V. Pavlova, Investigation of thermal properties of brick walls, insulated "outside" and "inside", Actual problems in construction and architecture, Education, Science, Practice, Materials of regional scientific 61.-technical conference on the results of the research in 2003, 2, 130 (SamGASA, Samara, 2003)

10. L. V. Pavlova, Prospects of development of the theory of thermal calculation of enclosures Actual problems in construction and architecture, Education, Science, Practice, Materials 62nd all-Russian scientific-technical conference on the results of the NIR, 2004 (SGASU, Samara, 2005)

11. L. V. Pavlova, the Defects of the exterior walls. Thermal protection, Construction Vestnik Russia Eng. Academy, Proceedings of the section "Construction" 6, 270 S. K., Ed Russia Eng. Academy (Moscow, 2005)

12. L. V. Pavlova, The development of theory of heat engineering calculation of protecting designs, Actual problems in construction and architecture, Education. Science, Practice, Materials 64 and all-Russian scientific-technical conference on the results of the research, 564 (2005) 
13. L. V. Pavlova, The Choice of insulation for exterior walls in brick buildings, Actual problems in construction and architecture, Education. Science, Practice. The materials of the 65th scientific and technical conference on the results of NIR SamGASA (SGASU, Samara, 2007)

14. L. V. Pavlova, The Reliability of the building envelope, Reliability of building objects: proceedings of the Xth international scientific-technical conference (September 2007), ed. by A. S. Lychev (SGASU, Samara, 2007)

15. L. V. Pavlova, The advantages and disadvantages of the design and operation of modern exterior walls, Actual problems in construction and architecture. Education. Science. Practice. The materials of the 66th scientific and technical conference on the results of NIR SamGASA for 2007 (SGASU, Samara, 2008)

16. L. V. Pavlova, Study of the temperature-humidity condition of external walls of energy efficient buildings, Actual problems in construction and architecture. Education. Science. Practice. The materials of the 66th scientific and technical conference on the results of NIR Samgasa in 2008, 11, 170-171 (SGASU, Samara, 2009)

17. S. F. Korenkov, Pat. 2298533 Russian Federation, IPC C04B14/46. Composition for the manufacture of hydrophobic mineral wool insulation materials / Korenkova S. F., Pavlov, A. A.; applicant and patentee VPO. No 2005121073/03; Appl. 05.07.2005; publ. 10.05.2007, bull. 13, (2007)

18. A. A. Pavlov, Statistical analysis of chemical compositions of sludge wastes, Building materials, equipment, technologies of XXI century, 6, 67 (Moscow, Publishing house LLC CSTI "Composite", 2007)

19. A. A. Pavlov, To the question about the use of a protective colloid coating for thermal insulation. materials based on mineral fibers, Roofing and insulation materials, 5(11), 26 (Moscow Publishing house LLC CSTI “Composite” 2006) 